abandon these activities, and he devoted himself to scientific research at Urach in Würtemberg. His principal work was connected with metabolism in the child, on which he published a classic entitled "Der Stoffwechsel des Kindes von der Geburt bis zur Beendigung des Wachstums" in 1894, for which he was awarded the Niepel Prize. He also studied the metabolism in obesity, gout, diabetes mellitus and chronic renal and cardiac disease. In 1908 he contributed two important articles to Pfaundler and Schlossmann's "Diseases of Children" on "Metabolism and Nutrition in the First Year of Life" and "Children's Growth in Weight and Height.". For some years he collaborated with Fechner, the experimental psychologist, in experiments on taste and touch. His interest in public health is shown by his papers on infant mortality and diphtheria. In recognition of his labours he was elected to an honorary doctorate of the Faculty of Natural Science of the University of Tübingen. He died on March 25, 1910.

\section{ASLIB Conference, 1942}

THE Association of Special Libraries and Information Bureaux has arranged a conference to be held during November 7-8 in the rooms of the Royal Society. The preliminary programme includes an address by Sir Richard Gregory on "International Systems and Standards", a symposium on the use of microfilm, and papers on library training and on war-time books and periodicals. Most of the papers will be available in advance. It is also announced that discussion groups are to be formed in provincial centres, where those unable to attend the London conference can meet to discuss the papers presented.

\section{The Nutrition Society}

A WHOLE-DAY conference of the Nutrition Society will be held at the London School of Hygiene, Keppel Street, London, W.C.1, on October 17, to discuss "Trace Elements in Relation to Health". Papers will be read by Dr. H. H. Green ("Significance of Trace Elements in Relation to Diseases of Plants and Animals"), Dr. R. L. Mitchell ("Distribution of Trace Elements in Soils and Grasses"), Prof. D. Keilin and Dr. T. Mann ("Copper, Zine and other Trace Elements in relation to Physiological Function and Enzyme Systems"), Prof. T. Dalling ("Enzootic Ataxia or 'Swayback' of Lambs in England in relation to Copper Feeding of Ewes during Pregnancy"-film with running commentary), Sir Charles Martin ("Cobalt and other Trace Elements in relation to Disease in Australasia"), Dr. W. Lyle Stewart ("Sheep 'Pining' in Britain"), Dr. M. M. Murray ("Fluorine in Human Nutrition; $a$, Biochemical Aspects"), Dr. D. C. Wilson ("Fluorine in Human Nutrition; $b$, Clinical Appreciation of Fluorine Distribution"), Mr. F. H. Kemp ("Fluorine in Human Nutrition; $c$, Radiological Investigations"), Mr. F. Blakemore ("Industrial Fluorosis of Animals in England"), Mr. W. S. Ferguson ("Teart' of Somerset; a Molybdenosis of Farm Animals"), Dr. R. A. MeCance and Miss E. M. Widdowson ("Absorption and Excretion ot Trace Elements"). The chair will be taken at the morning session by Dr. J. Russell Greig, and at the afternoon session by Prof. C. R. Harington. Further details of the Nutrition Society can be obtained from the hon. secretary, Dr. Leslie Harris, Nutritional Laboratory, Cambridge.

\section{Announcements}

Sir Henry Dale, president of the Royal Society, has accepted the directorship of the Laboratories of the Royal Institution, with the Fullerian professorship, in succession to the late Sir William Bragg. Sir Henry has expressed the wish that his appointment should be limited to a period of three years, so that the managers of the Royal Institution may then be free to consider their future policy.

Dr. Dudley Stamp has been appointed adviser on rural land utilization to the Minister of Agriculture. Dr. Stamp is director of the Land Utilization Survey of Great Britain and was vice-chairman of the Scott Committee on the utilization of land in rural areas.

DR. JoHN F. J. DiPPY, of the staff of Cardiff Technical College, has been appointed head of the Chemistry Department of Wigan and District Mining and Technical College, in succession to Dr. T. Heap, who has been appointed principal of Batley Technical College.

At the annual general meeting of the Physical Society held on October 2 the following officers were elected for the year 1942-43: President, Sir Charles Darwin; New Vice-Presidents, Prof. C. D. Ellis and Dr. H. T. Flint; Honorary Treasurer, Dr. C. C. Paterson; Honorary Secretaries, Mr. J. H. Awbery (Papers) and Dr. W. Jevons (Business); Honorary Foreign Secretary, Sir Owen Richardson; Honorary Librarian, Prof. L. C. Martin; New Members of Council, Mr. E. R. Davies, Dr. W. B. Mann, Mr. A. J. Philpot, Prof. H. C. Webster, Dr. W. D. Wright.

LORD HIRST OF WitTon, honorary member of the Institution of Electrical Engineers, has given $£ 20,000$ for the use of the Benevolent Fund of the Institution. It will be known as the Lord Hirst Fund to give assistance to applicants for help (or to their dependants) who have rendered important services to electrical science, or electrical industry or electrical engineering.

The Institute of Physics has arranged a discussion on the "Education and Training of Physicists", to be held at the Royal Institution on October 12. The discussion, which is to be in two sessions beginning at 10.30 a.m. and 2 p.m., will be based on the memorandum on the subject prepared by the Planning Committee of the Institute.

Already the Association of Scientific Workers has organized two conferences in London and two area conferences on the theme of "Science for Victory". A third area conference is to be held for South Wales at the Royal Hotel, Cardiff, on October 18. It will be in two sessions, beginning at 10 a.m. and 2.15 p.m. Five speakers lead each session, at the end of which there will be an hour for discussion. Abstracts may be obtained from the Association prior to the meeting.

THE name of Dr. Wadie Tadros should have been included as a joint author with Dr. J. M. Robson and Prof. A. Schönberg of the letter entitled "A New Synthetic Estrogen with Prolonged Action when Given Orally", published in Nature of July 5, p. 22. The omission arose through difficulties of rapid communication with Egypt. 